\title{
Pesantren Technopreneur: Pemberdayaan Ekonomi Komunitas Pesantren melalui Ekonomi Produktif Berbasis E-Commerce di Desa Tenajar Kecamatan Kertasemaya Kabupaten Indramayu
}

\author{
${ }^{1}$ Yayat Rahmat Hidayat ${ }^{*},{ }^{2}$ Tety Suciaty \\ *Corresponding Author: \\ E-mail: yayat.rahmat1982@gmail.com
}

${ }^{1}$ Program Studi Agribisnis, Fakultas Pertanian Universitas Swadaya Gunung Jati Cirebon, Indonesia ${ }^{2}$ Program Studi Agroteknologi, Fakultas Pertanian Universitas Swadaya Gunung Jati Cirebon, Indonesia

Received:

23 March 2021
Revised:

19 May 2021
Accepted:

05 October 2021
Published:

27 November 2021

\begin{abstract}
Abstrak
Penyesuian bentuk produk pangan harus dilakukan oleh sektor UMKM dalam rangka untuk merespon keingin konsumen atas berbagai produk yang ada di pasar. Salah satunya adalah konsumen pisang yang menginginkan berbagai olahan baik, olahan buah pisang sendiri maupun olahan bonggol dan pelepahnya. Hampir di banyak daerah pohon pisang dapat tumbuh subur dengan baik tidak terkecuali di Desa Tenajar Kecamatan Kertasemaya Kabupaten Indramayu. Salah satu pesantren yang memiliki usaha budidaya pisang adalah Pondok Pesantren Syubbanul Yaum. Usahatani pisang yang dijalankan oleh komunitas pesantren berjalan hampir lima tahun dengan jumlah anggota sebanyak 20 orang yang terdiri dari pengurus dan orang tua wali santri melalui lembaga ekonomi pesantren. Melalui kegiatan pengabdian ini diharapkan bisa memberi solusi untuk memberdayakan ekonomi komunitas komunitas dampingan. Kegiatan PKM ini laksanakan selama satu tahun mulai dengan urutan kegiatan yaitu; Sosialisasi kegiatan, Pelatihana pengolahan buah, bonggol pupuk organik, Pelatihan manajemen keuangan dan pemasaran berbasis e-commerce, Pendampingan untuk memfasilitasi terbentunya kelembagaan usaha yang professional dan berkelanjutan, Pendampingan kelembagaan untuk menjamin keberlanjutan kegiatan PKM dan evaluasi sebagai upaya untuk perbaikan atas metode dan program yang dilaksanakan. Hasil kegiatan PKM memberi dampak positif bagi komunitas dampingan yaitu meningkatnya kemampuan masyarakat didalam memanfaatkan bonggol pisang sebagai bahan untuk membuat pupuk organik. Selain itu komunitas juga memiliki keahlian didalam membuat konten pemasaran online, yaitu tersedianya group komunitas didalam memasarkan hasil olahan pisang, yaitu kripik pisang dengan konsep paking yang layak pasar. Melalui kompetensi ini secara memberi manfata bagi meningkatnya kemauan masyarakat untuk berwirausaha olahan buah pisang dan berdampak secara ekonomi yaitu meningkatnya kuantitas penjualan.
\end{abstract}

Kata kunci: Technoprenuer; ekonomi produkif; E-commerce; komunitas pesantren

\begin{abstract}
The SMEs sector must make adjustments to the form of food products in order to respond to consumer desires for various products on the market. One of them is banana consumers who want a variety of good preparations, processed bananas themselves as well as processed bananas and stems. Almost in many areas banana trees can thrive well, including in the Village of Tenajar, Kertasemaya District, Indramayu Regency. Some of the social institutions that work on banana cultivation are farmer groups, farmer cooperatives, and other social institutions such as Islamic boarding schools. One of the pesantren that has a banana cultivation business is the Syubbanul Yaum Islamic Boarding School. The banana farming
\end{abstract}




\begin{abstract}
which is run by the pesantren community has been running for almost five years with a total of 20 members consisting of the board and parents of the santri guardians through the pesantren economic institution. This PKM activity is carried out for one year starting with the sequence of activities, namely; Socialization of activities, Training on fruit processing, weevils of organik fertilizers, Training on e-commerce-based financial management and marketing, Assistance to facilitate the establishment of professional and sustainable business institutions, Institutional assistance for guarantee the sustainability of PKM activities and evaluation as an effort to improve the methods and programs implemented. The results of the PKM activities have had a positive impact on the assisted communities, namely the increase in the community's ability to use banana weevils as material for making organik fertilizers. In addition, the community also has expertise in creating online marketing content, namely the availability of community groups in marketing processed banana products, namely banana chips with a market-worthy gasket concept. Through this competency, it provides benefits for increasing the willingness of the community to entrepreneurship in banana processing and has an economic impact, namely increasing the quantity of sales.
\end{abstract}

Keywords: Integrative farming; E-commerce; farming sustainability

\title{
PENDAHULUAN
}

Kabupaten Indramayu merupakan salah satu daerah di Jawa Barat yang memiliki potensi sektor pertanian sangat bagus baik potensi komoditas tanaman pangan, hortikultura dan buah- buahan. Pada tanaman pangan Indramayu terkenal dengan daerah sentra produksi padi/ beras dan pada komoditas buah Indramayu terkenal dengan mangganya. Begitu juga pada buah pisang, Indramayu termasuk dikenal sebagai daerah sentra budidaya pisang. Salah satu wilayah yang masyarakatnya mengembangkan budidaya pisang adalah Desa Tenajar yang berlokasi di Kecamatan Kertasemaya Kabupaten Indramayu. Usahatani pisang banyak diusahakan oleh masyarakat, baik secara pribadi maupun kelembagaan sosial seperti kelompok tani, koperasi dan lembaga sosial lainnya seperti pesantren.

Pondok Pesantren Syubbanul Yaum merupakan lembaga pendidikan Islam di Desa Tenajar Kecamatan Kertasemaya Kabupaten Indramayu yang memiliki usahatani pisang. Setiap panen rata-rata menghasilkan 10 ton dengan rata- rata kapasitas kepemilikan lahan seluas 0,5 hektar. Usahatani pisang yang dikelola oleh Ponpes Syubbanul Yaum merupakan usaha yang dijalankan oleh anggota sebanyak 20 orang yang berposisi sebagai pengurus Ponpes dan wali santri yang berasal dari desa sekitar. Kapasitas produksi 10 ton per musim sebenarnya merupakan jumlah produksi yang banyak dan memiliki potensi untuk dikembangkan sebagai usaha yang berkelanjutan untuk pemenuhan kebutuhan keluarga kelompok mitra. Keterbatasan pengetahun dan teknologi yang dimiliki kelompok mitra mengharuskan mitra hanya menjual pisang tanpa ada upaya untuk meningkatan nilai tambah sehingga bisa mendapatkan keuntunga lebih besar. Salah satu upaya untuk meningkatkan nilai tambah pisang adalah dengan melakukan pengolahan buah pisang menjadi berbagai produk olahan makanan.

Mitra komunitas Pondok Pesantren Syubbanul Yaum Desa Tenajar Kecamatan Kertesemaya Kabupaten Indramayu secara kelembagaan memiliki potensi yang cukup besar. Hal ini didukung oleh kondisi kemauan sumber daya manusia yang tinggi didalam mengembangkan lembaga. Salah satunya mitra tergerak untuk membuka usaha bersama yaitu budidaya pisang yang dikoordinir oleh Ponpes. Kedua, usaha budidaya pisang yang sudah dilakukan oleh mitra merupakan bentuk usaha produkif yang bisa dikembangkan karena Desa Tenajar berpotensi untuk mengembangkan usahatani pisang. Namun pengembangan usaha ekonomi produktif ini masih terhambat beberapa kendala yang menjadi permasalah yang dihadapi oleh kelompok mitra. Beberapa permasalahan yang dihadapi oleh kelompok mitra diantaranya sebagai berikut:

1) Untuk mengembangkan menjadi usaha ekonomi produktif, mereka belum memiliki 
teknologi untuk pengolahan hasil buah pisang sendiri maupun pohon pisangnya menjadi beberap produk olahan makanan yang sebenanya memiliki potensi pasar cukup besar.

2) Usaha yang dijalankan kelompok mitra masih konvensional hanya baru sebatas usaha budidaya dan belum mengarah pada usaha yang lebih besar seperti pengolahan pisang dengan nilai ekonomi tinggi sehingga mereka belum menerapkan dan belum memiliki kemampuan untuk mengelola keuangan bisnis dengan baik.

3) Kelompok mitra juga belum memiliki strategi pemasaran yang baik apalagi pemasaran berbasis e-commerce sehingga jangkauan pemasarannya masih dekat dan belum maksimal berorientasi pasar.

4) Usaha yang mereka lakukan belum terkoordinir menjadi badan usaha yang professional dengan pola manajemen yang baik. Padahal mereka memiliki potensi dan kemauan yang tinggi untuk berkembangkan.

Solusi yang tawarkan pada kegiatan pengabdian ini adalah melakukan pemberdayaan komunitas pesantren dengan menggagas pesantren technoprenuer yaitu memberi bekal mitra supaya memiliki keahlian atau kreatifitas dengan kegiatan ekonomi produktif. Langkan solusi yang dilakukan adalah sebagai berikut:

1) Meningkatkan kemampuan mitra didalam mengolah komoditas pisang menjadi berbagai bentuk olahan makanan sehingga memiliki nilai tambah bagi peningkatan pendapatan komunitas pesantren. Kegiatan pada pengabdian ini adalah pelatihan pengolahan buah, bonggol dan pelepah pisang menjadi berbagai bentuk olahan makanan sehingga memiliki nilai tambah bagi peningkatan pendapatan komunitas pesantren di Desa Tenajar Kecamatan Kertasemaya Kabupaten Indramayu.

2) Membekali mitra agar memiliki kecakapan didalam pengaturan keuangan bisnis yang diajalankan sehingga menjadi lembaga usaha yang profesional. Kegiatan yang dilakukan adalah pelatihan manajemen keuangan bagi komunitas pesantren.

3) Memberi keahlian didalam memasarkan produk olahan pisang sehingga dapat menjangkau pasar yang lebih luas terutama pemasaran berbasis online melalui kegiatan pelatihan pemasaran berbasis e-commerce. Outcome Pelatihan ini adalah terbentuknya berbagai bentuk media pemasaran online.

4) Supaya kegiatan pengabdian ini bermanfaat, maka kegiatan lain yang dilakukan adalah melakukan pendampingan kelembagaan untuk menjamin keberlanjutan kegiatan PKM dan evaluasi sebagai upaya untuk perbaikan atas metode dan program yang dilaksanakan. Harapan kegiatan ini adalah terbentuk dan berjalannya kelembagaan usaha ekonomi produktif yaitu pengolahan pisang menjadi berbagai olahan makanan yang memiliki nilai ekonomi lebih tinggi.

Prioritas solusi yang ditawarkan pada PKM mengacu pada beberapa hasil penelitian yang sudah dilakukan oleh Tim pengusul maupun hasil penelitiannya. Hidayat (2018) hasil penelitiannya mengatakan bahwa salah satu upaya untuk mengentaskan kemiskinan (pemberdayaan ekonomi) pada masyarakat Desa Cibuntu Kecamatan Pasawahan Kabupaten Kuningan dilakukan dengan pengembangan potensi yang dimiliki masyarakat desa yang salah satunya adalah agrowisata. Pengembangan agrowisata didukung oleh adanya pengembangan usaha ekonomi produktif yaitu olahan dauh sereh menjadi minuman (Jasreh). Jenis minuman ini hingga sekarang dikenal banyak masyarakat bahkan luar kota. Luasnya pemasaran minuman Jasreh karena dilakukan dengan menggunakan media sosial bersama dengan promosi agro wisata desa Cibuntu. Berkembangnya usaha minuman Jasreh karena terbangunnya sinergitas antara program pembangunan dengan kondisi faktual desa yaitu potensi lokal yang tersedia.

Pengembangan usaha mikro diperlukan dukungan modal sosial baik pada sosial, kelembagaan, informasi maupun jaringan luar seperti pasar dukungan kelembagaan keuangan. 
Berbagai dukungan tersebut sebagai upaya untuk meningkatkan kinjera UMKM. Analia et al. (2019) dalam penelitiannya mengatakan jaringan UMKM yang terdiri dari informasi, kemudahan masuk pasar, organisasi dan inovasi berpengaruh signifikan terhadap kinerja UMKM. Aspek kinerja UMKM tersebut adalah; finansial, non finansial, modal intelektual, manajemen pengetahuan dan tanggung jawab sosial.

Agroindustri dibangun dengan tujuan dapat meningkatkan pendapatan karena dapat meningkatkan nilai tambah hasil budidaya. Upaya meningkatkan pendapatan usahatani baik pada level hulu maupun hilir dibutuhkan teknologi yang inovatif, ramah lingkungan dan bersifat lokalitas (potensi lokal). Hidayat et al. (2019) pada penelitian lain mengatakan bahwa penggunaan teknolog GAP sesuai SOP bepengaruh secara signifikan terhadap pendapatan usahatani mangga gedong gincu. Meningkatnya pendapatan usahatani ini mendukung tingkat kelayakan usahatani manga gedong gincu sebagai stimulus bagi pelaku usahatani yang lain sehinga termotivasi untuk melakukan usahatani hortikultura buah tersebut.

Selanjutnya Husniah et al. (2019), dalam penelitiannya mengatakan nilai tambah kerupuk tempe pada masing-masing skala usaha di Kecamatan Puger adalah positif dengan nilai tambah terbesar dimiliki agroindustri skala menengah sebesar Rp. 1.706,93 per kilogram bahan baku karena biaya penyusutannya lebih rendah diantara skala usaha lainnya. Pada penelitian menjelaskan perlu adanya usaha peningkatan nilai tambah produk melalui kegiatan pengolahan menjadi berbagai jenis produk sehingga dapat meningkatkan pendapatan usaha yang dijalankan.

Faqih et al. (2020) mengatakan bahwa peningkatan daya saing produk agroindustri perlu memperhatikan aspek sumber daya alam. Perhatian terhadap sumber daya alam dilakukan agar tujuan pembangunan pertanian berkelanjutan dapat terwujud. Keberlanjutan pembangunan itu sendiri dapat mendukung berajalannya sektor agroindusti sebagai sektor yang menyediakan produk pangan yang dibutuhkan oleh masyarakat. Hasil temuannya mengungkapkan ada hubungan antara sumber energy terbarukan, pengelolaan sumber daya alam, dan pengelolaan sumber daya manusia dengan keberlanjutan pembangunan pertanian.

\section{METODE PELAKSANAAN}

PKM dilaksanakan dengan menggunakan pendekatan metode Community Development Practice (CDP), yaitu alur kegiatan pemberdayaan masyarakat dengan pendekatan komunitas sebagai sasaran pemberdayaan. Metode ini memiliki tujuan agar komunitas sasaran dapat berdaya karena adanya stimulus dari pihak luar dalam hal ini berdayanya komunitas kelompoktani karena adanya program PKM yang dilakukan. Karena pendekatannya komunitas, metode ini mengharapkan adanya paratisipasi yang tinggi dari komunitas sehingga terbangunnya kemandirian komunitas sasaran. Alur pelaksanaan PKM yaitu sebagai berikut:

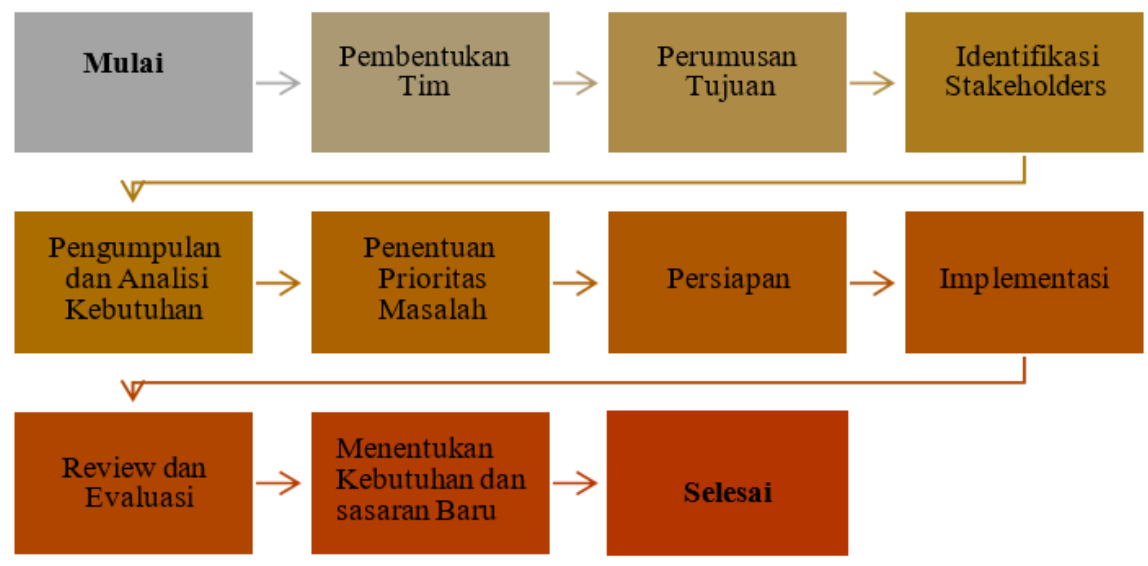

Gambar 1. Alur Pelaksanaan PKM 
1) Mulai, diawali dengan menyusun jadwal kegiatan dari awal hingga akhir.

2) Pembentukan Tim. Pembentukan Tim dilaksanakan dengan mengelaborasi antara Tim pelaksana PKM dengan tim di tingkat komunitas

3) Perumusan Tujuan. Selanjutnya merumuskan tujuan bersama dengan komunitas yang diawali dengan menyusun daftar masalah sehingga terstrukur secara baik.

4) Identifikasi Stakeholders. Identifikasi stakeholders dilakukan sekaligus membangun isu bersama sehingga pihak-pihak yang berkepentingan merasa terdorong dengan adanya kegiatan PKM ini.

5) Pengumpulan dan Analisis Kebutuhan. Pada tahap ini dikumpulkan sumber daya yang dimiliki termasuk tenaga sumber daya manusia baik sebagai Tim pelaksana PKM maupun pelaksana dari komunitas.

6) Penentuan Prioritas Solusi Masalah. Penentuan kegiatan sebagai tawaran solusi dibuat skala prioritas, artinya kegiatan mana yang segera dilaksanakan dan menyusul kegiatan yang lain sehingga kegiatannya benar-benar bermanfaat.

7) Persiapan. Setelah ditetapkan jenis kegiatannya kemudian mempersiapkan pelaksanaan kegiatan tersebut.

8) Implementasi. Pada tahap impelementasi kegiatan, semua Tim terlibat secara aktif sesuai dengan tugas masing-masing.

9) Pendampingan. Pendampingan dilakukan agar kegiatan dapat dijalankan oleh komunitas secara berkelanjutan sesuai dengan prinsip partisipasi dan berkelanjutan.

10) Review dan Evaluasi. Pada tahap ini dilakukan evaluasi yaitu melihat apakah semua program dapat berjalan dengan baik dan melihat bagaimana dampaknya atau manfaatnya. Apakah kegiatannya sudah efektif atau belum dan apakah kegiatannya dapat memberi solusi bagi permasalahan komunitas. Termasuk didalamnya memperbaikai jenis kegiatan dan metode baru yang lebih sesuai.

11) Menentukan Kebutuhan dan Sasaran Baru. Tahap ini dilakukan untuk menjamin keberlanjutan kegiatan yang harus dilaksanakan oleh komunitas sebagaimana prinsip pemberdayaan adalah sebagai sebuah proses yang terus dilaksanakan.

12) Selesai.

Strategi kegiatan dilakukan dengan mengutamakan partisipasi kelompok sasaran sehingga pengetahun mereka bertambah. Partisipasi dalam aktivitas riset dan pemberdayaan dilakukan yang salah satunya untuk keberlanjutan program sehingga kebutuhan dapat memenuhi kebutuhan mereka (Fujisaka, 1994). Partisipasi diartikan sebagai keikutsertaan, keterlibatan dan kebersamaan anggota masyarakat dalam suatu kegiatan tertentu baik secara langsung maupun tidak langsung (Kuswartojo, 1993) dalam Andry et al., 2020). Beberapa faktor yang mempengaruhi partisipasi adalah jenis kelamin, usia, tingkat pendidikan, tingkat pendapatan, dan mata pencaharian (Slamet, 1993)

\section{HASIL DAN PEMBAHASAN}

Bentuk kegiatan yang dilaksanakan pada program pengabdian ini di antaranya yaitu:

\section{1) Pelatihan pengolahan bonggol pisang menjadi pupuk organik}

Pelatihan ini dilaksanakan disalah satu rumah warga, yaitu anggota masyarakat yang memiliki usaha budidaya pisang. Peserta berjulam sepuluh orang yang terdiri dari rumah tangga yang sudah menjalanka usahatani tanaman pisang. 


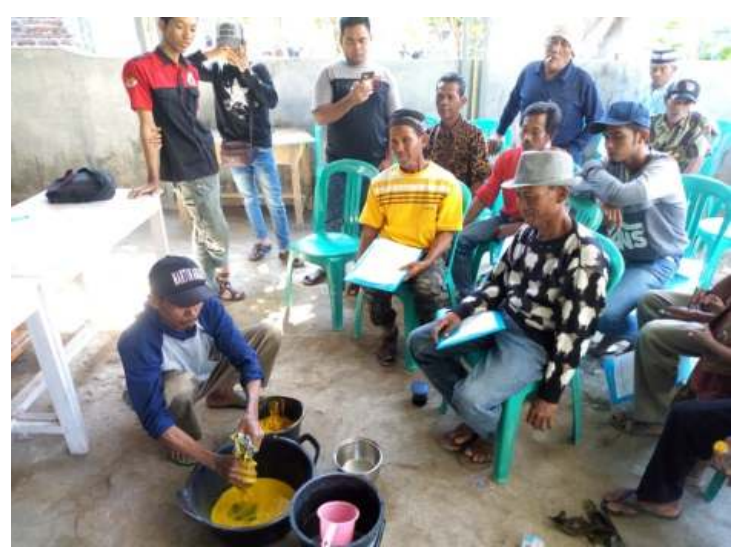

Gambar 2. Pelatihan pembuatan pupuk organik dari bonggol pisang

\section{2) Pelatihan Pengolahan Buah Pisang}

Pelatihan ini mengaharapkan adanya nilai tambah buah pisang sehingga dapat meningkatkan pendapatan usaha mitra. Beberapa produk olahan pisang yang dihasilkan adalah berbagai jenis rasa kripik pisang dan nugeht pisang.

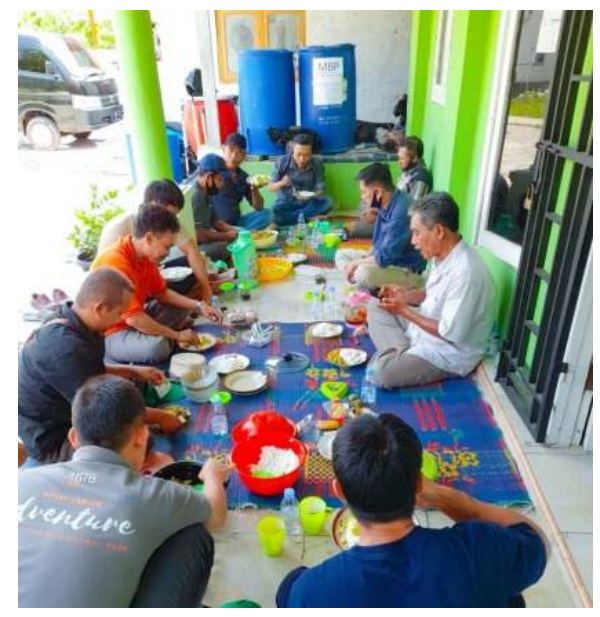

Gambar 3. Pelatihan pembuatan kripik pisang buah pisang

\section{3) Pelatihan pemasaran berbasis e-commerce}

Pelatihan ini dilakukan dengan tujuan agar komunitas memiliki keahlian didalam memasarkan produk hasil olahan pisang dengan basis teknologi informasi, yaitu tersedianya media pemasaran online. Pelatihan terdiri dari 10 orang yang merupakan komunitas pesantren, baik sebagai pengurus yayasan maupun orang tua santri. 


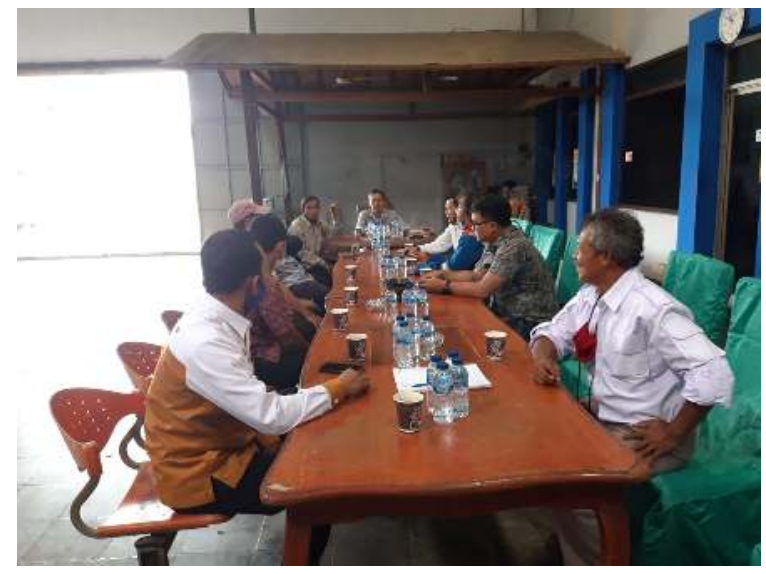

Gambar 4. Pelatihan e-Commerce

\section{Hasil Kegiatan}

Berdasarkan hasil kegiatan yang dilakukan pada program PKM menghasilkan beberapa poin yaitu sebagai berikut:

1. Kegiatan pelatihan pengolahan bonggol pisang memberi manfaat yang sangat besar bagi mitra yaitu mengetahui bahwa bonggol pisang dapat diolah menjadi pupuk organik. Pelatihan yang dilakukan juga secara nyata bermanfaat bagi warga yaitu mereka memiliki kemampuan untuk membuat pupuk organik dari bonggol pisan. Mitra yang mengikuti pelatihan adalah pengurus Yayasan dan wali santri yang memiliki usahatani pisang. Ratarata luas lahan usahatani budidaya pisang yang dimiliki mitra yaitu 0,5 hektar yang selama ini belum melalukan pengolahan bonggol pisang menjadi produk yang lebih bermanfaat.

Pupuk organik bongol pisang dapat dimanfaatkan oleh mitra sendiri untuk berbagai tanaman yang dibudidayakan oleh mitra ataupun untuk dijual dengan ketentuan sudah memiliki sertifikasi produk yaitu legalitas merek dan uji produk. manfaat pupuk organik sendiri adalah menghasilkan produk komoditas tanaman yang lebih sehat karena aplikais budidaya tidak memakai pupuk kimia atau sekurang-kurangnya mengurangi bahan kimia.

2. Pelatihan Pengolahan Buah Pisang merupakan kegiatan kedua yang dilakukan pada program PKM. Pelatihan ini bertujuan agar mitra menghasilkan produk yang memiliki nilai ekonomi lebih besar sehingga dapat meningkatkan pendapatan usaha. Nilai tambah kripik pisang daripada buah sendiri sebesar Rp. 20.000 dimana jika mitra menjual buah sendiri hanya sebesar Rp. 15.000 sedangkan olahan kriping pisang dijual dengan harga Rp. 35.000 per kilogram. Mitra yang mengikuti pelatihan tidak hanya mendapatkan materi. Tetapi mereka langsung mempraktikkan bagiamana membuat kripik pisang yang memiliki kualitas rasa baik dan bersih dan membuat berbagai rasa sehingga disukai oleh konsumen. Praktik pembuatan kripik pisang sendiri yaitu; menyeleksi buah pisang yang segar dan mencucinya agar getah bisa hilang, memotong buah pisang menjadi ukuran kripik dan dikeringkan. Setelah itu irisan buah pisang digoreng dengan tingkat pemanasan yang sesuai agar menghasilkan rasa kripik yang enak. Setelah itu memberi campuran rasa sesuai selera. Membuat bumbu berbagai rasa dibuat dari bahan alami agar mendapatkan produk makanan yang alami dan sehat.

3. Kegiatan yang ketiga yaitu pelatihan pemasaran berbasis e-commerce. Pelatihan ini mempekenalkan kepada komunitas dampingan agar mereka memiliki kesadaran produk berbasi pasar, yaitu bagaimana melakukan packing produk yang baik dan membuat media pemasaran online sehingga produk yang sudah dihasilkan dapat dipasarkan secar online dan menjangkau pasar yang lebih luas. Pelatihan ini dilakukan setelah mitra memiliki produk 
yang siap dipasarkan. Produk yang siap dipasarkan adalah pupuk organik dan olahan makanan yang terbuat dari buah pisang. Pada pelatihan ini sebelumnya mitra mendapatkan keahlian untuk melakukan packing produk dan membuat merek yang menarik dan layak untuk dipasarkan. Pada dasarnya pelatihan ini memperkenalkan metode pemasaran online dan cara melakukan pemasaran online kepada mitra. Beberapa aplikasi yang diperkenalkan pada mitra untuk pemasaran online adalah Shopee dan Lazada. Selain itu pelatihan ini memberi kemampuan kepada mitra didalam membuat aplikasi pemasaran online seperti pemasaran pada facebook, WA Group dan metode lainnya. Tujuan pelatihan ini adalah agar mitra mengetahui dan memiliki kemampuan didalam memasarkan berbagai produk sehingga dpat dijangkau ke pasar yang lebih luas.

\section{KESIMPULAN}

Berdasarkan hasil kegiatan dan uraian pembahasan di atas, maka dapat disimpulkan sebagai berikut: (1) Adanya kegiatan pelatihan pembuatan pupuk organik dapat meningkatkan pengetahuan masyarakat tentang mafaat bonggol pisang sebagai bahan pembuatan pupuk organik; (2) Komunitas dampingan memiliki kemampuan membuat pupuk organik; dan (3) Komunitas dampingan sudah memiliki media pemasaran online berupa instagram dan memiliki kemampuan untuk menjual produknya ke berbagai fasilitas penjualan online.

\section{UCAPAN TERIMA KASIH}

Kegiatan Pengabdian Pada Masyarakat dibiayai oleh Lembaga Pengabdian Masyarakat Universitas Swadaya Gunung Jati oleh karena itu kami ucapkan banyak terima kasih kepada Prof. Dr. H. Mukarto Siswoyo, Drs., M.Si selaku Rektor Bapak Harmono, SH., MH selaku Kepala Lembaga Pengabdian Masyarakat atas pendanaan dan kerjasamanya sehingga program PKM dapat berjalan dengan baik.

\section{DAFTAR PUSTAKA}

Analia, D., Syaukat, Y., Fauzi, A., \& Rustandi, E. (2019). Modal Sosial (Network) Upaya Meningkatkan Kinerja Usaha Mikro Kecil (UMK) di Kota Padang Sumatera Barat. Jurnal Ekonomi Pertanian dan Agribisnis, 3(1), 108-117. http://dx.doi.org/10.21776/ub.jepa.2019.003.01.11

BPS Kab. Indramayu, Kecamatan Kertasemaya Dalam Angka Tahun 2017.

Faqih, A., Roosganda, E., \& Azahari, D. H. (2020). The Increasing of Competitiveness of AgroIndustry Products Through Institutional Empowerment to Support the Achievement of Sustainable Agricultural Development. International Journal of Energy Economics and Policy, 10(5), 663. https://www.proquest.com/openview/23913f31f5ce7e08d5bf67821ce142bd/1?pqorigsite $=$ gscholar $\&$ cbl $=816340$

Fujisaka, S. (1994). Will farmer participatory research survive in the international agricultural research centres? Sustainable Agriculture Programme of the International Institute for Environment and Development.

Hidayat, Y. R. (2018). Model Pengembangan Agrowisata Berbasis Potensi Lokal dan Modal Sosial di Desa Cibuntu Kecamatan Pasawahan Kabupaten Kuningan. Prosiding Seminar Nasional Hasil Penelitian Agribisnis II: Peningkatan Ketahanan Pangan Rumah Tangga Pertanian. Fakultas Pertanian Universitas Galuh Ciamis, Hal. 190-197, ISBN 978-602- 


\section{Indonesian Journal of Community Services}

Volume 3, No. 2, November 2021

http://jurnal.unissula.ac.id/index.php/ijocs

DOI: http://dx.doi.org/10.30659/ijocs.3.2.174-182

61748-1-9

Hidayat, Y. R., Dwirayani, D., \& Saleh, I. (2019). Kajian Penerapan Teknologi terhadap Pendapatan Usahatani Mangga Gedong Gincu (Mangifera Indica L.)(Studi Kasus di Wilayah Kabupaten Majalengka dan Kabupaten Cirebon). Jurnal Ekonomi Pertanian dan Agribisnis, 3(1), 152-161. https://doi.org/10.21776/ub.jepa.2019.003.01.15

Husniah, F. A., Hapsari, T. D., \& Agustina, T. (2019). Analisis Nilai Tambah Agroindustri Kerupuk Tempe di Kecamatan Puger Kabupaten Jember. Jurnal Ekonomi Pertanian Dan Agribisnis, 3(1), 195-203. https://doi.org/10.21776/ub.jepa.2019.003.01.19

Rhonda, P, Pittman, R.H. (ed). (2009). An Introduction to Community Development. Routledge, 58-74

Andry, A., Utama, S. P., \& Widiono, S. (2020). Tingkat Partisipasi Petani pada Program Penguatan Kelembagaan Masyarakat Tani Berbasis Karet di Kabupaten Musi Rawas. Jurnal Ekonomi Pertanian dan Agribisnis, 4(3), 493-506. https://doi.org/10.21776/ub.jepa.2020.004.03.05

Kuswartojo, T. (1993). Peran LPSM Dalam Meningkatkan Partisipasi Masyarakat dalam Pembangunan Desa, Jakarta.

Slamet, Y. (1993). Pembangunan masyarakat Berwawasan Partisipasi, Sebelas Maret University Press. 